\title{
HIV/AIDS Perceptions and Vulnerability of Democratic Republic of Congo's Refugees Living in Durban, South Africa
}

\section{Ganzamungu Zihindula ${ }^{1,2}$, Kwaku Oppong Asante ${ }^{1}$, Anna Meyer-Weitz ${ }^{1}$ and Olagoke Akintola ${ }^{1,3}$}

\author{
${ }^{1}$ Discipline of Psychology, University of KwaZulu-Natal, Durban, South Africa. \\ gzihindula@gmail.com \\ ${ }^{2}$ International Training \& Education Center for Health (I-TECH) University of Washington and South \\ African National Department of Health
}

${ }^{3}$ School of Human and Social Development, Nipissing University, North Bay, Canada

\begin{abstract}
In South Africa, public perceptions of HIV/AIDS and people living with the virus have changed significantly but the refugees' communities are mostly left out, creating a sense of fear and vulnerability. Using an exploratory qualitative approach, this study explores HIV/AIDS perception and vulnerability among refugees living in Durban, KwaZulu-Natal, South Africa. A semi-structured interview was conducted with 31 purposively sampled participants consisting of seven males and 24 females, aged 23 to 60 years. The results from thematic analysis revealed that low perceived risk of HIV infection, fear of knowing HIV status and its associated stigma, lack of HIV prevention information and inadequate knowledge about HIV were the factors that make refugees vulnerable to HIV infection. These findings underscore the need for culturally appropriate HIV treatment, awareness, and education and prevention programmes for refugees living in South Africa, with particular focus on gender and power dynamics within relationships.
\end{abstract}

Keywords: HIV/AIDs perception, Vulnerability, Refuges, South Africa, DRC

\section{Introduction}

Southern Africa is faced with a burden of disease resulting from many causes including war, poverty and lifestyle. The region accounts for $67 \%$ out of the 33.3 million people living with HIV globally and $70 \%$ of 1.7 million HIV related-deaths that occurred in 2011 (Mwai et al., 2013; UNAIDS, 20I5). The ongoing migration from northern African countries to Southern Africa region and the failure of the governments in implementing health policies to address the challenges, as well as establishing a sustainable health system, are major issues needing attention. Simmons (20/3) noted that people become vulnerable to HIV transmission following conflicts, displacement, food insecurity and poverty which altogether leads to forced migration. According to Cassels et al (20|4), despite the link between HIV and forced migration remaining complex and linear, findings from a recent study suggest that HIV transmission risks and refugee vulnerability are amplified by a myriad of factors (Tanaka et al., 2008).

Further unavailability of epidemiological data in the regions of the African continent undergoing civil unrest and armed conflict, leading to the damages caused by HIV /AIDS to remain largely unknown (Ramjee and Daniels, 20I3). What is known however is the unfortunate fact that both HIV infection and conflict disproportionately affect sub-Saharan Africa. The region represents only $10 \%$ of the world's population but it accounts for $70 \%$ of the global new HIV infections. Of the 35 million people living with HIV (PLHIV) globally, sub-Saharan Africa accounts for 24.7 million PLHIV and I.5 million new infections. In 2013 alone, I.I million people died of AIDS-related causes (UNAIDS, 20I4). Out of the above total, the Democratic Republic of Congo (DRC) accounts for a total of 450,000 PLHIV, with an estimate of I.1\% HIV prevalence among age group 15 to 49 , - the most affected age group in all other countries in the region (CDC, 20I4; UNAIDS, 20I4, 20I5).

South Africa, which has over six million people living with HIV, also hosts more refugees than any other country in the sub-region. Of the 449,000 refugees in the sub-region, South Africa alone hosts 65,223 refugees, excluding the undocumented and uncounted asylum seekers (UNHCR, 2013). Moreover, all HIV/AIDS prevention policies in South Africa have focused on the citizens and left out the refugee community by not including them in any of its 
HIV prevention strategies as well as in their HIV/AIDS National Strategic Plans [NSPs] (Munyewende, 20I I; Shisana et al., 20l4; Weine and Kashuba, 20l2). Although, countries that host refugees should be responsible for the protection and well-being of refugees, this has not been the case for many countries including South Africa (Shisana et al., 2014; UNHCR, 20I5; Weine and Kashuba, 20I2). This study was conducted in order to explore the HIV/AIDS perceptions and vulnerability among refugees living in the city of Durban in South Africa. Such a study is of great importance not only because it is the first of its kind being conducted amongst refugees in the city of Durban but also because it documents serious issues that allows the researchers to provide a detailed list of issues that expose refugees to HIV/AIDS vulnerability. The study focused on refugees from DRC as they are the third largest group of refugees hosted by South Africa (UNHCR, 20I5; Zihindula et al., 20I5).

\section{Literature Review}

Refugees are always excluded from the national health care systems of the countries in which they reside (Amara and Aljunid, 20 I4; Langlois et al., 2016; WHO, 2006). A study by the Centre for Disease Control [CDC] (2013) points out that Voluntary Counselling and Testing (VCT) was not provided to urban refugee populations. Similarly, Crush and Tawodzera (2014) commented that even when such services are available, refugees still face challenges of documentation, language and negative attitudes from health care providers. All these destabilizing factors have been shown to increase the risk for HIV infection, which can be exacerbated by refugees having limited knowledge of HIV transmission and methods of prevention (Krause et al., 2015) thus, rendering them vulnerable to the epidemic.

There is limited research that has been conducted to explore the perceptions and HIV/AIDS vulnerability of refugees in sub-Saharan Africa, and specifically in South Africa. Most of these studies investigate knowledge, attitudes and practice of HIV prevention (Tanaka et al., 2008), others focused on refugees' perceptions regarding HIV/AIDS but did not test their vulnerability (Nkwinika et al., 20I4), while a few others only explored refugees' HIV education needs (Tompkins et al., 2006). These studies suggest that refugees should be educated on HIV and that the latter should benefit from sexual and reproductive health services available. These studies were conducted in South Africa and did not examine refugees' vulnerability to the epidemic. This study was conducted in order to explore the HIV/AIDS perception and vulnerability among refugees living in Durban, South Africa.
The term vulnerable population was introduced as part of the guidelines for medical ethics in the Nuremburg Code of 1949 (World Medical Declaration of Helsinki, 2008), and the 1979 Belmont Report to protect human subjects involved in research (National Institute of Health, 20 I0; Park and Grayson, 2008). For the purpose of this study, a vulnerable population is defined according to the WHO (2014) as people who are particularly vulnerable to HIV infection in particular situations like migrants, prisoners and street children. In this context, the refugees are considered as vulnerable on the basis of their being exposed to a situation that influences their vulnerability to the infection.

\section{Theoretical and Conceptual Frameworks}

This study was guided by the theory of masculinity advanced by Connell (1987) and the health belief model (Becker, 1974; Rosenstock, 1966). Connell's theory of masculinity allowed an understanding of the complex interplay between gender and power in the society studied (Connell, 1987). This theory involves three structural models including sexual division of labour, sexual division of power and structure of affective attachments. These three structures exists at different levels like family, society and institutions which maintained by social mechanisms. Some researchers have suggested that the power differences based on gender inequality within Africa, including the Democratic Republic of Congo (DRC), have led to dominance of patriarchal ideologies giving way to male gender dominance over female gender (Adomako, 2006; Kondemo, 20II, Sa and Larsen, 2008; Wingood and Diclemente, 2000). Studies within the African context (Adomako, 2006; Kapinga, 2010; Kondemo, 20II; Mbonu et al., 2010) have suggested that gender and power play a big role in a continued oppression as well as men's dominance over women in the DRC. In applying the theory of gender and power to this study, the researchers explore the gender dimension in refugee communities' belief, their risk perceptions and their health care seeking behaviours related to HIV. It is therefore suggested that gender and power may play a significant role in men's dominance over and oppression of women, thus exposing women to sexually transmissible infections including HIV.

In addition to Connell's gender and power theory, this study was guided by the health belief model (Becker, 1974; Rosenstock, 1966). This theory contains four "basic components" that are thought to promote or inhibit health relevant actions. These basic components include subjective perceptions of (I) vulnerability to the negative event, (2) severity of the negative event, (3) benefits of specific preventive actions, and (4) barriers to performing preventive 
actions. In the original version of the model, perceived vulnerability, severity, and benefits of the preventive behaviour were joined together to form a product term (Hochbaum, 1958; Leventhal et al., 1960), although more recent studies have not assumed a specific combinational formula (Weinstein, 1993). Nonetheless, at the later stage, Weinstein (1993) was able to test the four competing theories of health protective behaviours. Perceived personal vulnerability is usually depicted as a necessary (but not sufficient) motivator of precautionary behaviour. In addition, both the original model and its more recent reinterpretation (Becker and Rosenstock, 1987) suggest that emotionality may influence the person's real perception of threat. Rogers (1975) compliments this model with the suggestion that the original formulation of the protection theory, which was designed to investigate the effects of persuasive messages on the adoption of health-protective behaviours, provided details on ways in which emotions can influence ways in which human beings view or perceive threats. According to this second model (protection motivation theory), the information about a health hazard stimulates a cognitive appraisal of vulnerability to the negative event. Frederick et al. (1996) view this appraisal as a mediator of the persuasive effects of the message by arousing a motivation to protect oneself. It is that motivation, according to the theory, that arouses, sustains, and directs preventive or protective behaviours. Thus, perceived vulnerability is a major factor in the development of motivation to avoid risk.

\section{Methodology \\ Research Design}

This study used a qualitative research design. This approach was suitable for the study as it enabled the researchers to develop an understanding of social life and to discover the subjective meaning that people construct and attach to their actions (Neuman, 20II). The design also provides opportunity for "thick and rich" descriptions of the issues relating to HIV/AIDS vulnerability and to offer the chance to individuals whose voices are rarely heard to express their concerns (Ulin et al., 2002).

\section{Participants and sampling}

This study was conducted among DRC refugees in Durban, KwaZulu-Natal, South Africa. Durban was selected given that the province is less researched on refugees' health yet it is one of the most burdened by diseases and hosts a substantial number of refugees from the Democratic Republic of Congo (Lakika, 20II; Muzumbukilwa, 2007; UNHCR, 2015; Zihindula et al., 2015). Purposive sampling was used to recruit participants in this study as it allowed the researchers to select participants who are able to provide rich information about the phenomenon that is being studied (Creswell, 2009). One suitable purposive sampling strategy is snowball technique, used for locating participants by asking one key informant to identify individuals who have experienced a similar phenomenon (Ulin et al., 2002). The issue of bias following such sampling method was avoided by ensuring that the key informants do not refer us to their friends only but instead helped to recruit another fellow refugee. Participants were included in the study if they met the following inclusion criteria: being a DRC refugee living in Durban, aged 18 years and over, and had lived in South Africa for two or more years. Based on this, the sample in this study comprised 31 participants, made up of seven males and 24 females between the ages of 23 and 60 years. The number of male participants was lower than that of females because the males were not willing to participate in the study. The study was meant to interview more than the current number of participants but information saturation was reached at respondent number 31 during the interviews.

\section{Procedure}

The study was approved by the Humanities and Social Science Research Ethics Committee of the University of KwaZulu-Natal, Durban, South Africa (Ethical clearance number: HSS/0739/0I3D. A semistructured interview guide was used to collect the data, as it allowed the researchers flexibility to probe and ask follow-up questions. Participants who agreed to participate in the study signed an informed consent form, and agreed that the interviews can be taperecoded, after the aims and objective had been explained. Interviews were conducted in French and/or Swahili (by the first author) and at the convenience of participants. These two languages were used because they are the home-spoken languages of the refugee community being studied. The interview schedules covered the following issues: general knowledge and awareness of HIV and AIDS, perceived risk of HIV infection, HIV tests taken by refugees, HIV/AIDS prevention methods, disclosure of HIV status and access to ARTs for refugees. Interviews were conducted in a place chosen by the respondents. Prior to the interviews, a briefing session was held with each of the respondents describing the objectives of the study and seeking consent for their involvement. Appointments were made with the respondents based on their availability. During the first meeting, participants were informed of their rights to voluntarily withdraw from the study at any time should they feel the need. Confidentiality was also explained and all respondents 
were assured that their names would be removed from any material, and the data collected would be stored safely and locked away, with access granted only to the researcher and the staff of the discipline of health promotion. Each interview took, on average, between 30 minutes and two hours. The study was voluntary and participants did not receive any form of inducement or reimbursement. The interviews were translated by the first author and transcribed verbatim to English.

\section{Data Analysis}

Thematic analysis by Braun and Clark (2006) was used to analyse all the transcribed data. The first step in analysing the data for this study involved familiarizing and immersing oneself with the data to be analysed. Patterns of all common themes were identified (Ulin et al., 2002). The second step involved identifying themes that shared the same words, styles and terms that were used by participants. These themes were used to set up connections. Themes that emerged from the text were used, displayed in detail then reduced to essential points under major themes stated in the objectives. The third step in data analysis is coding. The data was marked according to themes using the research questions as a guide. Step four involved the breaking down and coding of the data into themes. Different concepts that were expressed by the participants in several ways were grouped together under a single theme. Each theme was then elaborated on in more detail. The final step involved putting together the interpretation of the data, and checking it (Terre Blanche et al., 2006).

\section{Results}

\section{Demographic characteristics of respondents}

All the participants $(\mathrm{N}=3 \mathrm{I})$ in this study were forced out of their country of origin due to three primary causes including war, violation of human rights and persecution. The participants' socio-demographic characteristics are presented in Table I. The majority of the participants $(\mathrm{N}=24)$ were females with the remaining 7 been males. Approximately $80 \%$ of the participants were unemployed, and over half $(55 \%)$ had secondary level of education. Refugees' limited level of education has serious implications for their access to health care services and employability which in turn affects affordability of private health care services. Participants ages ranges from 23 to 60 years, and $77 \%$ of the participants were married. The married respondents had in total 54 children and half of them were in their reproductive age. This is consistent with the country's (DRC) total fertility rate (TFR) of 7.00 despite two decades of war and financial crisis. As shown in Table I, interviews were conducted at many different places. As indicated above, some respondents were found in their homes, churches, work places and in the researchers' vehicle. Those interviewed in their homes, were not feeling well. Many of them indicated that their situation has been deteriorating in the past year. The respondents' perception of their health status was classified as: ill, very ill, "well" and others. The respondents classified under "very ill" are those who were even unwell at the time of the interviews, while the "well" represented those who were averagely well. Those who reported neither ill nor well were grouped among others After the analysis of the qualitative data, five (5) theme which were found to influence HIV/AIDS perception and vulnerability of refugees are highlighted are presented below. 
Table I: Demographic characteristics of participants

\begin{tabular}{|c|c|c|}
\hline Status & Numbers & Percentages \\
\hline \multicolumn{3}{|l|}{ Gender } \\
\hline Male & 7 & 23 \\
\hline Females & 24 & 77 \\
\hline \multicolumn{3}{|c|}{ Employment Status } \\
\hline Employed & 3 & 10 \\
\hline Unemployed & 25 & 80 \\
\hline Students & 3 & 10 \\
\hline \multicolumn{3}{|l|}{ Marital Status } \\
\hline \begin{tabular}{l|l} 
Single \\
\end{tabular} & 5 & 16 \\
\hline Married & 24 & 77 \\
\hline Divorced & 2 & 7 \\
\hline \multicolumn{3}{|c|}{ Educational Levels } \\
\hline \begin{tabular}{l|l} 
Tertiary \\
\end{tabular} & 7 & 23 \\
\hline Secondary & 17 & 55 \\
\hline Primary & 4 & 13 \\
\hline Not educated & 3 & 10 \\
\hline \multicolumn{3}{|c|}{ Health Status of respondents } \\
\hline \begin{tabular}{l|l} 
Sick \\
\end{tabular} & 5 & 16 \\
\hline Very sick & 14 & 45 \\
\hline Well & 6 & 19 \\
\hline Others & 6 & 19 \\
\hline
\end{tabular}

\section{Refugees' knowledge about HIV/AIDS in South Africa}

The results from this research revealed that Congolese refugees living in Durban are have limited knowledge about HIV prevention strategies in Durban. Some respondents indicated that because of their relatively poor socio-economic status, they do not have access to TV or newspapers. Other participants who were engaged in informal employment reported lack of adequate time to rest, let alone follow the news. It is also obvious that the refugees are not familiar with the language through which most of the messages are communicated. This alone in addition to the instability that life imposes on them, creates a situation where these individuals become less interested in such crucial information especially when not much refugee health- related information is documented. A few of the refugees indicated different sources through which they get to know about HIV/AIDS in the country and others reported having any knowledge at all.

"I know nothing about HIV in this country. I only hear people talking about it. I am not sure if I am protected from infection or not" (IDI\#24, Male).

"I learned from school that HIV [rate] is high in South Africa, but I have no other information about how it infects or affects me and my family" (IDI\#27, Female).

These respondents pointed out that they were not aware of the level of HIV epidemic in the country, and this suggests that they have very limited information regarding the epidemic. Other refugees also reported different sources of information pertaining to HIV/AIDS in the country.

\section{Perceived HIVIAIDS infection risk}

A question to assess the perceived risks of contracting HIV infection was included in the interview guide. The respondents were asked if they considered themselves at risk of HIV, as well as their knowledge about the virus. The majority of the refugees indicated that they were aware of HIV and AIDS and its significance but many, especially the women, did not think they were at risk of contracting it.

"I do not consider myself at risk of HIV infection even though my partner always travels, but I trust him" (IDI\# I, Female).

"I do not think that I am exposed to the HIV infection at all. I do get tested whenever I go to the 
hospital especially during pregnancies. I do not care about the HIV at all, but all I need is a treatment for my current illness" (IDI\# 26, Female).

Among the reasons cited by respondents regarding their carelessness about HIV infection were: trusting partners, and no information about different sources through which people contract the infection. The respondents showed limited knowledge about their risks of contracting the HIV infection. Most of these responses came from female respondents. The limited perceived risk of contracting HIV is reflected in the refugees' reluctance to condoms.

\section{Condom use among Congolese refugees}

The issues around trust and the position of Congolese women in the society place them in a situation where they cannot easily negotiate the use of condoms in a relationship because men are not cooperative with regards to adhering to reproductive health advices. Less than half of the total number of respondents indicated having used a condom. As reported above, married couples indicated that they trust each other not to use condoms, while other respondents suggested that the facilities where condoms are collected are not confidential. The stigma and stereotypes following a refugee woman who collects a condom at the clinic plays a great role, and underplays women's rights to accessing and utilizing health care services.

"My husband told me that we can never use a condom because he trusts me and I trust him as well. One day I told him that at the family planning we are advised to use a condom at specific times. Since that day he said I will never go to the family planning anymore" (IDI 27, Female).

"We had a conversation about using a condom and my husband said that he is now suspecting me of cheating. He said that it is not in our tradition that a married couple should use a condom for any reason" (IDI 3I, Female).

Over half of the respondents indicated that they are afraid to collect a condom from the health facility because of the likelihood of been accused by their partner of infidelity should they be seen.

\section{Testing for HIV}

Of the 24 females who took part in this study, only four had taken HIV tests together with their partners. Others took the tests alone while the rest had not taken any test, especially the participants who were single. It was also found that lack of trust between partners influenced the HIV testing among the participants.

"I have tested twice in my life for HIV. First it was in my country and the second time here in South Africa and this was because of pregnancy and I did not know I was being tested for HIV' (IDI \#3, Female).

While some respondents indicated having never taken an HIV test, women stated that they only take HIV tests during pregnancy visits to the clinics. Despite the recommendations that married couples should be accompanied by their partners at family planning sessions, respondents in this study reported that this does not occur. Among the reasons they cited were the refusals of their partners to go to the clinics, others indicated that their partners are usually at work during the clinic visiting hours. A few others indicated that their partners' culture does not allow a man to take a test together with a woman as it shows disrespect.

"I have been taking HIV tests but I always go alone because my husband does not buy in at all. I am always motivated in taking the test and I do not care if my husband infects me because I was told that in South Africa an HIV positive woman can deliver safely and the baby will not be infected" (IDI\#25, Female).

The quotes above reflect a lack of male cooperation, lack of knowledge and information. These were reported to be influenced by gendered dimension in the society under study. An estimate of one out of ten Congolese refugees will take the initiative to go to the hospital to screen for HIV. Besides the reported fear of the refugees for testing and not being able to access treatment once diagnosed as HIV positive, other factors do affect testing. All the female respondents pointed to issue of partners/husbands as one dominant barrier, where men do not take part in couple and family testing for HIV and AIDS. This cultural way of doing things gives a man the power not to take a test, yet they are sexually active. This raises issues of gender disparity among the Congolese refugees and its implication for their health. The refugee women have limited control over their reproductive choices. For instance, dependency on male partners for decisions on contraceptive practice puts them at serious risk. In addition, women refugees are poorer than men refugees and this frustrates their efforts to protect and promote their health and that of their children. Ultimately, the different attributes and roles that the Congolese society assign to males and females profoundly affects 
their ability to protect themselves against HIV/AIDS and to cope with its impact.

\section{Barriers to taking a HIV test}

Knowledge of one's HIV status is crucial for the benefit of their entire family and the community at large. However, not all men agree to take a test for different reasons which could be cultural, religious or social. According to the respondents in this study, men's specific reasons for not taking a test were very different from those of women. The most dominant barriers cited by women included patriarchal dominance in society, fear that the partner will abandon her if he discovers that she has taken an HIV test, the concern about the future if one tests HIV positive, as well as the fact that counselling is always conducted in the local language (IsiZulu) which they do not understand. From the men's perspectives, they indicated that they would rather go to work, for fear of losing their jobs than going to the nearest clinic for an HIV test. Other men indicated that even after the test they will not be provided with treatment if found to be HIV positive. Others mention issues around identity documents without which they cannot be treated.

"I was tested two months ago but my partner never tested since our marriage. At the antenatal care, we are requested to invite our partners to be tested but our men do not consider that option" (IDI\# I, Female).

This quote points to the importance of gendered and cultural dimensions of HIV/AIDS in the Congolese community. The quote also explains how much men are failing to accept responsibility in the spread of the disease. In most cases, men were accused of being the reason why women who have tested held back from disclosing their HIV status.

\section{Fear of disclosure and suicide}

Fear of knowing one's HIV status and stigma attached to the disease were shown to result in fear of disclosure. This demotivates them from taking a test or disclosing after being tested. This phenomenon was easily understood by the researchers based on the fact that until now being HIV positive in DRC comes with stigma and it is considered to be almost taboo.

A refugee who receives an HIV positive diagnosis in the KwaZulu-Natal province confronts serious challenges. This is explained by the fact that refugees have a problem in accessing antiretroviral therapy. They are denied access to such treatment, as the respondents reported when they were asked to tell what they think could happen to them if they tested HIV positive:

"It is not a death sentence if I become HIV positive, but the fear is that I might find it hard to be treated because our hospital does not give ARTs to refugees at all. I will also tell no one that I am HIV positive" (IDI\# 29, Male).

The quote above reflects one of the reasons for refugees not taking up a test for HIV. While some respondents perceived being HIV positive as normal, others viewed it as an end to life. In addition to this observation, one respondent adds:

"It is a big challenge if I happen to be diagnosed HIV positive because I know that they ask for a green ID card to get $A R V$, yet I do not have the green identity document" (IDI\# I5, Female).

Refugee documentation is a great barrier to accessing health care services in Durban. Yet among the respondents, only one refugee reported having qualified for permanent residency so far. Furthermore, none of the refugees disclosed his or her status during the interviews. This poses a question of how the respondents know that they cannot access ARVs without the green ID. One has also to verify if refugees are denied access and utilization of the ARVs throughout South Africa or if this is only practiced in the city of Durban. The researcher has also observed that the response to the disease varies and depends on an individual's perceptions. Not all the respondents believed that they could continue to live with the disease especially when they do not have access to treatment. A few others reported:

"If I happen to be told that I am HIV positive, I can commit suicide instead of thinking about medication which I will not qualify for and also because it is a very bad disease" (IDI\# 3I, Female).

"If I happen to be diagnosed HIV positive, I can just commit suicide and die because I will not get treatment with my refugee status and the community will reject me" (IDI\#3, Female).

Desperation, confusion and stress are some of the reasons that push people into committing suicide. For a Congolese refugee, committing suicide is not a result of the few cited reasons but because he/she will not access treatment for the disease. Refugees therefore perceive themselves not only at risk of the infection but as likely to die from the infection. In this vein, the perceptions of personal vulnerability to HIV 
are reflections of current and recent conditions under which one lives and the degree of exposure to contract HIV or develop AIDS. It is evident that KwaZulu-Natal has the highest HIV prevalence in South Africa. Unfortunately, research suggests that access and utilization of health care services by a noncitizen remains challenging.

The quotes above reveal that for the Congolese community in Durban becoming HIV positive could be a death sentence. Among the participants, none believed that he/she can still live after being diagnosed HIV positive. Curiously, little has been done in the community to raise awareness and understanding that people can live much longer with HIV if they are put on treatment. Unfortunately, over half of the respondents indicated that they could just commit suicide if they tested HIV positive. Hence for a Congolese refugee, there is no hope or no reason to live after they become HIV positive. Some of the quotes provide deep insight into the reasons for refugees' fear of becoming HIV positive. In most cases their reasons were attached to the inaccessibility and no-utilization of the treatment by the refugees. Some respondents said:

"Being HIV positive is not the end of the world to me but the fear is that I might have a problem to be treated because our Addington Hospital next to us does not give ARVs to refugees" (IDI\#29, Male).

More than 25 respondents gave similar responses to the above. This similarity is a sign that there is a perception of a lack of option for refugees who are diagnosed HIV positive. Hence many of the refugees are living a risky life, presenting a risk not only to refugees but to the local community as well.

\section{Sources of HIV prevention information among the refugee community}

The majority of the respondents who had heard of HIV/AIDS responded that their perceived leading sources of influence regarding HIV prevention were 'Television Broadcast Messages', the 'refugee community itself' and the 'hospital/clinics' health posts'; the latter were more dominant among female respondents. Unfortunately, these women reported that all information contained in these sources were written either in English or IsiZulu which they cannot read. The main source of information about HIV/AIDS for refugees is therefore a fellow refugee. Yet this is not a reliable source. More than half of the respondents indicated:

"I learned about HIV prevention method from a friend, not at the clinic" (IDI 2, Female).
"I learned about HIV from a training called "CROSSROADS" that was organised by our local community church. If it lasted for more than two days I was going to learn a lot. Unfortunately, the training was only for one day. Also the facilitator's accent was hard for me to hear everything because he was an American" (IDI\# 3I, Female).

There are limited sources of information on HIV/AIDS for refugees. According to the refugees, they only get to learn about the epidemic through some open opportunities which do not last long. There is a need to find out if camp-based refugees face a similar challenge as those who are self-settled, like those in South Africa.

\section{Discussion}

This study was conducted to explore HIV/AIDS perceptions and vulnerability of Democratic Republic of Congo's refugees living in Durban, South Africa. The themes discussed are refugees' knowledge about HIV/AIDS, their perceived risk of HIV infection, the reluctance to take up a HIV test and its barriers, the fear of disclosure and stigma for those who test, limited condom use and the source of information about the epidemic amongst refugees.

Refugees' knowledge of HIV/AIDS in South Africa remains very low. Studies conducted in the country suggest that their lack of knowledge is attributable to the myth regarding the epidemic (Nkwinika et al., 2014). A study of DRC refugees' knowledge, attitudes and experiences of HIV/AIDS was conducted in Cape Town and yielded results suggesting that there is limited and almost no knowledge of HIV/AIDS among the study participants (Kalawu, 20I5). According to the authors, this is based on the fact that refugees in Cape Town are not included in any strategy or plan to fight the epidemic (Kalawu, 2015). Similar studies on Ethiopian, Eritrean and Syrian refugees revealed similar results (UNHCR, 2015). This limited knowledge was shown to contribute to the refugees' low perceived risks of contracting HIV/AIDS infection.

The responses from female refugees are an indication that they know very little regarding their exposure to HIV infection. This lack of knowledge is further influenced by the societal and cultural powers invested in men. These values imply that there is a high degree of trust toward a man where a woman living in a heterosexual relationship still believes that she is not at risk of getting infected. Although living in the province with the highest incidence of infection (Shisana et al., 2014), some of the participants, especially women, did not believe that they could be 
exposed to HIV infection. This denial makes it hard to prevent or treat the disease. Amnesty International (Al) reports that one of the biggest obstacles to HIV prevention and treatment is poor knowledge or denial about HIV status and the associated risks (Al, 20l2). This ultimately influences condom use, as many would have already been living in denial.

Findings in this study concurred with existing literature on condom use among the refugee population globally. A study conducted among refugees in a refugee camp in Tanzania revealed similar findings. Tanaka et al. (2008) indicated that condom use among refugees was very low compared to condom use among the Tanzanian community. It is estimated that in Africa, $80 \%$ to $90 \%$ of HIV infection occurs through heterosexual intercourse (UNAIDS, 20I4), and condom use is one of the most effective ways to reduce transmission of HIV (Nkwinika et al., 20l4; O'Laughlin et al., 20I3; UNHCR, 2015). Moreover, consistent with the findings, a limited use of condoms among both single and married refugees was reported in this study. This is based on the fact that there is no known existing health education programmes for the refugee community. As indicated in this study, participation in family planning sessions, as indicated by the participants, had not been beneficial as a result of the language barrier in communication. The above are some of the reasons for refugees reporting low uptake of HIV testing in this research study, and this health seeking behaviour renders them vulnerable to HIV.

Similar research has revealed that heterosexual men remain one of the main modes of transmitting HIV (Hughes and Saxton, 2015). However, although in some cases the mother will have contracted the virus from another man; in the majority of cases, men indirectly transmit the virus to their children by first transmitting HIV to their mother. Men also learn that they have the virus only when a child is diagnosed with AIDS and in such circumstances some men initially deny they have contracted HIV (Hellandendu, 2012; Muller and Moyo, 20II). Anecdotal evidence suggests that this mode of transmission is typical to the Congolese community where a man takes no HIV test and cannot accompany the wife to family planning sessions or to antenatal care. A number of studies have suggested that such men will blame the women for being the ones who are infected (Hellandendu, 2012; MacDonald, 1996; Muller and Moyo, 20I I). Furthermore, just like women have to prove their womanhood through motherhood, in many societies, fatherhood is a cultural obligation (Austin, 20I3). Other research reveals that men, and specifically Africans, become fathers not only to provide proof of their virility but most importantly to also perpetuate the family name (Lesetedi, 2014; Ratele et al., 2012).

Little research has been undertaken to explore the relationship between fatherhood and HIV/AIDS. Many men who do not attend family planning sessions are unaware that they and/or their female partners have HIV and only discover they have the virus when a child has AIDS-related illnesses (Lesetedi 2014; MacDonald, 1996; UNAIDS, 2004). Despite the Prevention of Mother-To- Child Transmission (PMTCT) recommendation to every pregnant woman to be tested (HOD, 20l4), some refugee women who are pregnant are still lagging behind, as research has shown that not many of the refugee women use the PMTCT services due to the language barrier and lack of identification as well as their cultural beliefs (Apalata et al., 2007; SAMP, 2015; UNHCR, 20I5; Vearey, 20I4).

Findings in this study are consistent with the above; suggesting that in the refugee community under-study, only a very limited number of the participants had taken an HIV test. Out of the 3I respondents, only nine had taken an HIV test and only one respondent disclosed his status. Others are faced with different types of barriers as highlighted above, including the fear that they will not be able to access ARVs to treat their illness, as refugees have no access to ARVs in Durban (Apalata et al., 2007; Mujawamaria, 2013; Muzumbukilwa, 2007; Zihindula et al., 20I5). Refugees' limited access to ARVs alone is a key factor influencing their vulnerability to HIV.

Moreover, in this study, refugees were seen to be socially and politically excluded, yet these social exclusions alone contribute to their reluctance to test for HIV. To address this issue, an aggressive national campaign was launched in South Africa in April 2010, to encourage 15 million sexually active individuals to be tested for HIV. At the end of the campaign in June 20I I, I4.8 million counselling sessions and I 3 million tests for HIV were completed, although the number of patients who tested positive was not known. Furthermore, the report showed that the campaign focused on citizens and not on refugees, resulting in the number of refugees who took up a test being unknown (Shisana et al., 20l4). Being unable to give the exact number of refugees who tested during such a big campaign is perceived as a one of the challenges facing refugees in accessing health care services and contributes to their vulnerability to the epidemic.

Findings in this study remain inconsistent with existing literature regarding fear of disclosure of HIV status by refugees. Studies have shown a reduction in HIV-related stigma in many countries including India, 
New Zealand, South Africa and Kenya respectively (Earnshaw et al., 2013; Gurnani et al., 201 I; Hughes and Saxton, 20I5). This doesn't seem to be the case for Congolese refugees living in Durban. The respondents were prompted and asked what they would do if they happened to receive an HIV positive diagnosis. Their responses suggested that they will commit suicide, leave the country for a place where they will not be seen by their community members, and others indicated that they would go to churches for prayer. These responses highlighted a lack of consistent and reliable sources of HIV-related information for refugees.

Findings in this study are consistent with previous research suggesting that there are limited options and sources of information available for refugees about methods of HIV prevention in South Africa (Apalata et al., 2007; O'Laughlin, 20I5; Zihindula et al., 20I5). Many refugees reportedly rely on their friends for any information related to HIV/AIDS. Although some citizens still face challenges related to their health, research confirms that there is a huge gap between refugees and the local population's level of vulnerability to HIV/AIDS in South Africa (Apalata et al., 2007; Lakika, 20II; UNHCR, 20I3). The very same failure of messaging leads to the refugee community failing to use condoms, although it is one of the most commonly known methods of prevention.

\section{Limitations}

This study has some limitations. The small sample size limits the generalisability of the results to the entire community of refugees in South Africa, as their experiences may vary between provinces and by age and gender. Additionally, the sensitive nature of the topic under study might have influenced the outcome, as some were reluctant to participate in the study.

\section{Conclusion}

Refugees living in the city of Durban remain vulnerable to HIV/AIDS. Most of the aspects that render them vulnerable suggest the need for health policy to address health care services provision for refugees. Refugees on the other hand have to revisit their cultural beliefs and perceptions of illnesses, taking into consideration that forced migration must have influenced their ways of health seeking behaviours. Findings in this study call for refugees to consider prevention as a priority for their well-being. They are to break some cultural barriers and move beyond HIV-related stigma to early seeking of medical attention. The provincial Department of Health together with the refugee community can jointly make a difference in fighting the transmission of the virus. Finding from this study suggest that the Congolese refugee community represents a population vulnerable to HIV infection and disease. On this basis, HIV screening should be offered to refugees upon their arrival in the country and the provision of counselling, ART, Prevention of Mother to Child Transmission of HIV and family planning should be facilitated by organisations concerned with refugees in South Africa.

\section{References}

Amnesty International 2012, Women, HIV/AIDS and human rights, Accessed on 22/04/2015 from https://www.amnesty.org/download/Documents/.. .amr010022006en.pdf

Adomako, A.A 2006, Intimates bargains: sex workers and free women negotiate their sexual space in Oppong, $\mathrm{C}$ et al (Eds), "Sex and Gender in an era of AIDS: Ghana at the turn of the millennium" (pp. 137-168). Accra: Sub-Saharan Publishers.

Amara, H.A \& Aljunid, M.S 20I4, "Noncommunicable diseases among urban refugees and asylum-seekers in developing countries: a neglected health care need". Globalization and Health, 10, 24, http://doi.org//0.II86//744-860310-24

Amisi B.B 2005, Social capital, social networks and refugees migration: an exploration of the livelihood strategies of Durban Congolese refugees. Unpublished MA Thesis submitted at the University of KwaZulu-Natal, Durban South Africa.

Apalata, T., Kibiribiri, E. T., Knight, S., \& Lutge, E 2007, Refugees' perceptions of their health status and quality of health care services in Durban, South Africa: A Community -Based Survey. Durban, South Africa: Health Systems Trust.

Austin, W.M 2013, Rights and obligations, USA: Eastern Kentucky University, Internet Encyclopedia of Philosophy

Becker, M. H 1974, "The health belief model and personal health behaviour", Health Education Monographs, Vol 2, PP. 324-508

Braun V, \& Clarke, V 2006, "Using thematic analysis in psychology" Qualitative Research in Psychology, Vol, 3, no2, pp. 77-I0I

Cassals, S., Jenness, M.S \& Khanna, A 2014, "Conceptual Framework and Research Methods for Migration and HIV Transmission Dynamics". AIDS Behaviors, Vol, 18 no. 12 pp. 2302-23। 3

Connell, R.W 1987, Gender and power, society, the person and sexual politics, London, UK: Blackwell Publishers. 
Cresswell, J.W 2007, Qualitative Enquiry and Research Design: Choosing among five approaches $\left(2^{\text {nd }}\right.$ edn). Thousand Oaks, CA: Sage

Creswell, J.W 2009, Research Design: Qualitative, Quantitative, and Mixed Methods Approaches, Thousand Oaks, California: Sage Publications.

Crush, J., \& Tawodzera, G 2014, "Medical xenophobia and Zimbabwean migrant access to public health services in South Africa", Journal of Ethnic and Migration Studies, Vol. 40 no. 4 pp. 655-670

DOH 2014, Department of Health-Annual Report 20/2-20/3, Republic of South Africa: National Department of Health

Earnshaw, V.A., Bogart, L, M., Dovidio, J.F., Williams, D.R 20।3, "Stigma and racial/ethnic HIV

disparities: moving toward resilience". American Psychology, Vol, 68(4):225-36

Frederick, G. M., Gibbons, X., \& Bushman, J. B I966, "Relation between perceived vulnerability to HIV and precautionary sexual behaviour", Psychological Bulletin, Vol I 19, no 3, pp.390-409

Gurnani, V., Beattie, T.S, Bhattacharjee, P., Team, C.F.A.R., Mohan, H.L., Maddur. S., et al 20II, "An integrated structural intervention to reduce vulnerability to HIV and sexually transmitted infections among female sex workers in Karnataka state, south India". BMC Public Health, Vol, II, no 755 pp. I- 12

Hellandendu, M.J 20I2, "Contributory factors to the spread of HIV/AIDS and its impacts in sub-Saharan African countries" European Scientific Journal, Vol. 8, No. 14, pp- |857-788|

Hochbaum, G 1958, Public participation in medical screening program: A sociopsychological study, (U.S. Public Health Service Publication No. 572). Washington, DC: U.S. Government Printing Office

Hollander, C.A., Bruce, D., Ekberg, J., Burstrom, B., Borrell, C \& Ekblad, S 20I2,"Longitudinal study of mortality among refugees in Sweden", International Journal of Epidemiology, Vol 4I, pp||53-| |6I. doi: 10.1093/ije/dys072

Hughes, J.A \& Saxton, J.P 2015, "Thirty years of condom-based HIV prevention by gay men in New Zealand" New Zealand Medical Journal, Vol I 28 no. I 426 pp. 4-6744

Kalawu, C 2015, Exploring HIV/AIDS knowledge, attitudes and practices of Congolese refugees in Cape Town Unpublished M.A Thesis submitted in the faculty of economics and management science at Stellenbosch University in South Africa.

Kapinga, L 2010, Comment la femme vit-elle au Congo Kinshasa la pendemie du VIH/SIDA dans le cadre du marriage? Accessed on 19/April/2015 from: http://www.communicationsansfrontieres.net/edit o.html

Kondemo, M.M 20II, Women's Security through Heterosexual Marriage in the Democratic Republic of the Congo: An African Woman's Reading of the Book of Ruth. An Unpublished MA Thesis submitted at the University of South Africa. Krause, S., Williams, H., Onyango, A.M., Sami, S., Doedens,W., Giga, N., Stone, E \& Tomszyk, B 2015, "Reproductive health services for Syrian refugees in Zaatri Camp and Irbid City, Hashemite Kingdom of Jordan: an evaluation of the Minimum Initial Services Package", Conflict and Health, Vol 9 no.l pp.54

Lakika, D.M 20II, Understanding illness and Treatment seeking behaviour among Congolese Migrants in Johannesburg, (Unpublished Master's Thesis) University of Witwatersrand: Johannesburg, South Africa

Langlois, V.E., Haines, A., Thomson, G \& Ghaffar, A 2016, "Refugees: towards better access to healthcare services". The Lancet, Vol 387 no 1016 pp. 3|9-32|

Lesetedi, N.G 2014, "Rethinking Gender within the context of the Global HIV/AIDS Epidemic", Wagadu Volume 2: Summer ISSN: I545-6I96

Leventhal, H., Hochbaum, G. M., \& Rosenstock, I 1960, The impact of Asian influenza on community life: $A$ study in five cities, (U.S. Public Health Service Publication No. 766). Washington, DC: U.S. Government Printing Office

MacDonald, D.S 1996, "Notes on Socio-Economic and Cultural Factors Influencing the Transmission of HIV in Botswana". Social Science and Medicine, Vol 42, no.9 pp. I325-I 333

Mbonu, N. C., Van den Borne, B., \& De Vries, N. K 2010, "Gender-related power differences, beliefs and reactions towards people living with HIV/AIDS: an urban study in Nigeria". BMC Public Health, Vol 10 nol, pp-334

Moyo, N. \& Müller, J.C 20II, "The influence of cultural practices on the HIV and AIDS pandemic in Zambia," HTS Teologiese Studies/Theological Studies Vol, 67, no.3 Art. No770:5 doi. 10.4102/hts.v67i3.770

Mujawamaria, C 2013, Living with Xenophobia: understanding the lived experiences of Burundians and Rwandese refugees in South Africa, Unpublished M.Sc. Thesis Submitted at the University of KwaZulu-Natal, Durban

Muzumbukilwa, W 2007, The impact of government migration policies on foreigners known as "AMAKWEREKWERE" in South Africa, Unpublished MA Thesis submitted in the School of social policy, University of KwaZulu-Natal 
Mwai, W.G., Mburu, G., Torpey, K., Frost, P., Ford, $N$ \& Seeley, J 2013, "Role and outcome of community health workers in HIV care in subSaharan Africa: A systematic review". Journal of the International AIDS Society, Vol, 16, nol pp18586

National Institutes of Health 2010, Office of Human Subjects Research: Regulations and ethical guidelines. Accessed on 29/01/2016 from http://ohsr.od.nih.gov/guidelines/index.html

O'Laughlin, N.K., Rouhani, A.S., Faustin, M.Z \& Ware, C.N 2013, "Testing experiences of HIV positive refugees in Nakivale Refugee Settlement in Uganda: informing interventions to encourage priority shifting", Conflict and Health, Vol, 7, no.2, DOI: 10.1 I86/I752-I505-7-2

Pillay, P \& Black, V 2012, Safety, strength and simplicity of efavirenz in pregnancy, Johannesburg: Wits Reproductive Health and HIV Institute (WRHI), University of the Witwatersrand

Ramjee, G \& Daniels, B 2013, "Women and HIV in Sub-Saharan Africa", AIDS Res Ther, Vol, 10, no. 30 doi: 10.1 I86/1742-6405-10-30

Rogers, R. W 1975, "A protection motivation theory of fear appeals and attitude change", The Journal of Psychology, Vol, 91 no. I, pp. 93-II4

Rosenstock, L. M 1966, "Why people use health services”, Milbank Memorial Fund Quarterly, Vol, 44, no 94

Sa, Z, \& Larsen, U 2008, "Gender inequality increases women's risk of HIV infection in Moshi Tanzania", Journal of Biosocial Science, Vol, 40, no.04, pp.505-525

Sheaffer, R 20I0, Health Gap South Africa: Improving Migrants' Access to Health Care, HRW accessed from:

https://lists.mayfirst.org/pipermail/healthgap/2009December/001246.html

Shisana, O, Rehle, T, Simbayi LC, Zuma, K, Jooste, S, Zungu N, Labadarios, D, Onoya, D et al 2014, South African National HIV Prevalence, Incidence and Behaviour Survey 20/2, Cape Town, HSRC Press

Simmons, E 2013, Harvesting Peace: Food Security, Conflict, and Cooperation (Environmental Change \& Security Program report vol. 14, issue 3), Washington DC: Woodrow Wilson international Center for Scholars

Tanaka, Y., Kunii, O., Hatano, T \& Wakati, S 2008, "Knowledge, attitude and practice (KPA) of HIV prevention and HIV infection risks among Congolese refugees in Tanzania", Health and Place, Vol, I4, no. 3, pp. 434-452

Terre Blanche, M., Durrheim, K., \& Painter, D. (Eds) 2006, Research in Practice: Applied methods for
Neuman, L 201I, Social research methods: Qualitative and quantitative approaches (7th Eds.). New York: Pearson International.

Nkwinika, E., Khoza, B.L., Lebese, T.R., \& Shilubane, N.H 2014, "Refugees' perceptions regarding HIV and AIDS in Ba-Phalaborwa Municipality in Limpopo Province" Journal of Interdisciplinary Health Sciences, Vol 19, nol

the social sciences. Cape Town, South Africa: University of Cape Town Press

Tompkins, M., Smith, L., Jones, K., \& Swindells, S 2006, "HIV education needs among Sudanese Immigrants and refugees in the Midwestern United States", AIDS and Behaviour Vol, I0, no 3, pp. 319-325

Ulin, P. R., Robinson, E. T., Tolley, E. E \& McNeill, E. T 2002, Qualitative methods: A field guide for applied research in sexual and reproductive health, North Caroline, USA: Family Health International

UNAIDS 2014, Fact Sheet 2014, UNAIDS. Accessed on $10 / 11 / 2014 \quad$ from:

http://www.unaids.org/sites/default/files/en/media/ unaids/contentassets/documents/factsheet/2014/2 0140716 FactSheet en.pdf

UNAIDS 2015, How AIDS changed everything, Geneva: UNAIDS

UNHCR 2010, Policy on refugee protection and solutions in urban areas September 2009 accessed on $14^{\text {th }} \quad$ May 2013 from: http://www.unhcr.org/refworld/docid/4ab8e7f72. $\underline{\mathrm{html}}$

UNHCR 2013, Inter-Agency Regional Response for Syrian refugees, Health and nutrition bulletin for Egypt, Iraq, Jordan, and Lebanon, Issue no. 10

UNHCR 20I5, Syria regional refugee response: interagency information portal, Government of Turkey: UNHCR

UNHCR 2015, UNHCR country operations profileSouth Africa: The UN Refugee Agency Accessed on $20^{\text {th }} / 08 / 2015$ from: http://www.unhcr.org/pages/49e485aa6.html

Vearey, J 2014, "Healthy migration: A public health and development imperative for South (ern) Africa", South African Medical Journal, Vol 104 no 10, pp. 663-664

Weine, M.S \& Kashuba, B.A 20I2, "Labour migration and HIV risk: a systematic review of the literature". AIDS Behaviour, Vol, 16, no 6, pp. $1605-162 \mid$

Weinstein, N. D 1993, "Testing four competing theories of health protective behaviour", Health Psychology, Vol I2, pp. 324-333 
WHO 2004, The Right to Health: Fact Sheet No 31. Geneva: World Health Organization

Wingood, GM \& Diclemente, R.J 2000, "Application of the theory of gender and power to examine HIV-related exposures, risk factors and effective interventions for women", Health Education and Behaviours, Vol, 27, pp. 539-565

Zihindula, G., Meyer-Weitz, A, \& Akintola, O. 2015, "Lived experiences of Democratic Republic of
Congo Refugees facing Medical Xenophobia in Durban, South Africa", Journal of Asian and African Studies, DOI: I0.1I77/0021909615595990

Zihindula, G., Meyer-Weitz, A., Akintola, O. 2015, "Access to health care services by refugees in Southern Africa: A critical review of literature", Southern Africa Journal of Demography, Vol, 16 no.I 